\title{
Factorial Composition of a General Self-Efficacy Scale in Mexican University Students
}

\author{
Grabriel Gastelum Cuadras, (Dr) \\ Perla Jannet Jurado Garcia, (MP) \\ Susana Ivonne Aguirre Vasquez, (MP) \\ María de los Angeles Bibiano Mejia, (MP) \\ Autonomous University of Chihuahua / México
}

doi: 10.19044/esj.2016.v12n28p430 URL:http://dx.doi.org/10.19044/esj.2016.v12n28p430

\begin{abstract}
The present study aims to investigate whether the psychometric results proposed by (Sanjuan, Perez, \& Bermúdez, 2000) for general selfefficacy scale replicate. The total sample was of 282 subjects; 142 women and 140 men, college students from the city of La Paz Baja California Sur Mexico, with an mean age of 20.3 years $(S D=1.6)$ for women and 20.9 years $(\mathrm{SD}=1.6)$ for men. The factorial structure of the questionnaire was analyzed by confirmatory factor analysis. The analysis shows a feasible and appropriate factor structure. The structure of a one factor, based on statistical and substantive criteria, has shown adequate fit indicators of reliability and validity. In addition, the factor obtained a Cronbach's alpha coefficient of .914. Future research should replicate these findings in larger samples.
\end{abstract}

Keywords: Self-efficacy, factorial structure, construct validation, structural equations

\section{Introduction}

Bandura (1986) in his social cognitive theory emphasizes the role of self-referential phenomena as the way in which the individual is able to act in his environment and consequently transform it, individuals create and develop self-perceptions about their capacity, perceptions that become the means by which they pursue their goals and make their decisions (Asbún \& Ferreira, 2004; Gutierrez, Ampara \& Carminal, 2011). That is, the way people act, is the product of the intervention of their beliefs about what they are capable to do.

Self-efficacy is defined as "people's judgments about their capabilities to achieve certain performance levels" (Bandura, 1997). Therefore, is not enough to be able to do something, the person must be 
judged himself capable. Be able to use the abilities and personal skills to a variety of circumstances, including emotional reactions that are experienced in difficult situations (Ornelas, White, Gastelum, \& Chavez, 2012; Schmidt, Messoulam, \& Molina, 2008).

The beliefs that people have about themselves represent a basic factor for the achievement of their activities or in their decision-making that they will face throughout their lives. The greater perceived efficacy, the greater degree of effort invested and the greater persistence in achieving the goal; very important situation for a person, who is in a learning process, to be successful (Bandura, 1997; Pérez et al., 2011). Definitely, self-efficacy beliefs are a cognitive mechanism that mediates between knowledge and action and determines, among other factors, the success of the own accions (Coal \& Merino, 2008; Ornelas, Blanco, Rodriguez, \& Flores, 2011; Zimmerman \& Kitsantas, 2005).

As an example of the importance of self-efficacy in the academic sphere, we can say that this reveals why people with the same level of skills and knowledge present behaviors and/or different results, or why people act in dissonance with their skills (Bandura, 1982; Pérez et al., 2011). Therefore, self-efficacy beliefs in one's ability are indispensable to master the academic activities; since students that trust in their capabilities are more motivated to achieve their goals (Á. Blanco, 2010); hence the importance of education to strength the development of academic competence in students and encourage skills that enable them to believe in their own capacities (Carbonero \& Merino, 2008; Ornelas et al., 2011).

From the Social Learning Theory of Bandura, is then assumed that self-efficacy expectations are an important predictor of the intentions and actions of individuals facing various situations: because a high level of perceived self-efficacy has been shown as a protective element which increases the motivation, reduces emotional disturbances, and at the same time improves healthy behaviors and physical care. In fact, compared to how difficult it can be to encourage the adoption of behaviors that promote health or stop harmful behavior against it, self-efficacy has consistently shown to be a major factor (Olivari \& Urra, 2007).

For all the above, this research is based on the premise that the perceived academic self-efficacy is an important mediating factor in how people feel, think, motivate and behave; so measuring the perception of academic self-efficacy in the learner is extremely important in the study of how to facilitate progress and educational success, as well as to minimize the risk of leaving school (Peguero \& Shaffer, 2015; Shkullaku, 2013).

The present instrumental study (Montero \& León, 2005) is aimed to provide empirical support for the factorial division proposed by Sanjuán et al. (2000) for the General Self-efficacy Scale; which it is justified by the 
importance of checking the factorial structure of the instrument and the psychometric equivalence of it in different groups; since in the context of intergroup comparison, it is essential to consider the need to conduct the adaptation of an instrument of psychological measure that would meet all the criteria of equivalence, but above all, consider whether the same factorial structure is applicable to different groups of subjects or, more generically, to different populations (Abalo, Levy, Rial, \& Varela, 2006).

\section{Methods}

\section{Participants}

The sample of 282 participants, 142 (50.4\%) women and 140 (49.6\%) men Mexican university students, was obtained by convenience sampling. Women ages range between 18 and 24 years, with a mean of 20.3 and a standard deviation of 1.6 years; and men fluctuate between 18 and 24 years, with a mean of 20.9 and a standard deviation of 1.8 years.

\section{Instrument}

General Self-Efficacy Scale by Baessler and Schwarzer (EAG) adapted by Sanjuan et al. (2000), evaluates the stable sense of personal competence to effectively manage a variety of stressful situations. In the Spanish version of the questionnaire applied to Spanish university students, an internal consistency of .87 was obtained (Sanjuan et al., 2000).

For our study two adaptations were made: First adaptation, in the original scale is scored with five responses, in the version used in this investigation, the subject chooses between eleven possible responses, in a scale of 0 to 10 , this first adaptation is justified in relation to which subjects are accustomed to the scale of 0 to 10 , as it is like that they have been evaluated by the education system in our country (Mexico). Viciana, Cervello, and Ramirez (2007) report a similar change in the validation of a scale with a Spanish population. Second adaptation, the scale was computed and applied by a computer.

\section{Procedure}

The university students of Paz Baja California Sur México were invited to participate in the study. Those who agreed to participate signed the voluntary consent.

The instrument described above was applied using a personal computer using the administrator module of the instrument of the scales editor version 2.0 (H. Blanco et al., 2013), in a session of about 30 minutes. At the beginning of each session students were given a brief introduction on the importance of the study and how to access the instrument; they were asked the utmost sincerity and they were guaranteed the confidentiality of 
the data obtained. Instructions on how to respond were in the first screens; before the first instrument item. At the end of the session they were thanked for their participation. Once the instrument was applied, data was collected by the results generator module of scales editor, version 2.0 (H. Blanco et al., 2013).

\section{Data analysis}

The first step in analyzing the psychometric properties of the questionnaire was to calculate the mean, standard deviation, skewness, kurtosis and discrimination indexes of each item. Then remove of the scale those who obtain a kurtosis or extreme asymmetry, or a discrimination index below 0.30 .

Then, were submitted to comparison two models: AG-1-10, that corresponds to a unifactorial structure according to the original distribution of the items in the questionnaire and AG-1-7, which responds to the structure of the previous model eliminating items that were not well enough explained.

To conduct the confirmatory factorial analysis, AMOS 21 software was used (Arbuckle 2012), variances in terms of error were specified as free parameters, in each latent variable (factor) a structural coefficient was set associated to one, so that scale was equal to one of the observable variables (items). The estimated method used was the maximum likelihood; following the recommendation of Thompson (2004), so when the confirmatory factorial analysis is used, it is necessary to verify not only the adjustment of the theoretical model but it is recommended to compare the fit indexes of some alternative models to select the best.

To evaluate the fit model, statistical chi-squared, the Goodness-of-fit index (GFI), and the root mean square error of approximation (RMSEA) were used as absolute adjustment measures. Adjusted goodness of fit index (AGFI), the Tucker-Lewis Index (TLI) and the comparative fit index (CFI) as measures of increasing adjustment. The chi-squared fit index divided by degrees of freedom (CMIN/GL) and the Akaike Information Criterion (AIC) as adjusting measures of Parsimony (Byrne, 2010; Gelabert et al., 2011).

Subsequently was calculated the reliability of each of the dimensions, of the measurement models obtained, through Cronbach's alpha (Elosua \& Zumbo, 2008; Nunnally \& Bernstein, 1995) and Omega coefficient (Revelle \& Zinbarg, 2009; Sijtsma, 2009).

\section{Results}

Descriptive analyzes and discrimination indexes

In Table 1 are summarized the results of the descriptive analysis and the discrimination indexes (total-item correlation corrected) of each of the 10 items on the questionnaire in the total sample. The answers to all items 
reflect mean scores ranging between 7.22 and 7.90, and standard deviation offers, in all cases, higher values than 1.50 (within a response range between 0 and 10). All values of skewness and kurtosis are within \pm 1.5 ; so is inferred that the variables are reasonably fit to a normal distribution. Regarding discrimination indexes of all items, they discriminate satisfactorily by discrimination indexes above 0.50 (Brzoska \& Razum, 2010).

\section{Confirmatory Factorial Analysis}

The global results of confirmatory factor analysis (GFI 0.867; RMSEA 0.133, 0.899 IFC) for the AG-1-10 model corresponding to a unifactorial structure according to the original distribution of the items in the questionnaire indicate that the measurement model is not acceptable (Table 2).

The Factor of the AG-1-10 model explains about 59\% of the variance and according to the results shown in Table 3 , three of the 10 items saturate below .70 in its intended dimension (items 1, 3 and 10).

The global results of the confirmatory factor analysis (GFI 0.960 ; RMSEA 0.082; CFI 0.978) of the second model tested (AG-1-7) that corresponds to the structure of the previous model eliminating items that were not well enough explained, indicate that this measurement model is better than the previous and that its fit is optimal (Table 2). The factor of this model explains approximately $66 \%$ of the variance.

Furthermore according to the results of Table 4, all items saturate above .70 in its intended dimension.

The factor model AG-1-7 obtained internal consistency values equal to or above $0.70(\Omega=0.916$ and $\alpha=0.914)$; showing a very high internal consistency for this type of scales.

\section{Conclusion}

The main objective of the study was to investigate whether or not the psychometric results proposed by Sanjuán et al. (2000) are replicate for the General Self-efficacy Scale through a sample of Mexican university students using a confirmatory factor analysis (CFA).

The confirmatory factor analyzes made, after removing three of the 10 items of the scale, support the unifactorial structure proposed by Sanjuan et al. (2000) that demonstrates an adequate internal consistency, at the same time that the factor obtained present appropriate standardized factor saturations, saturations which correspond to the proposed structure of the questionnaire

In summary, the analysis of the psychometric properties of the questionnaire, have shown that a unifactorial structure is viable and appropriate in accordance with established psychometric requirements. The structure of single factor, based on statistical and substantive criteria, has 
shown adequate fit indicators, reliability and validity. However, the scope of these results is limited, and it is necessary further research to confirm the structure obtained, which will allow counting with more robust evidence regarding the factorial structure of the scale. Specifically, it must be demonstrated if the invariance of the structure of the scale is accomplished by gender and age, among others; so that, is considered that more studies are needed in order to confirm or refute the data obtained in investigations carried out so far.

Regarding the limitations of the study, the participants were volunteers, Mexican students, which limits the generalizability of the results. Therefore, repeating the process with broader samples (adding young adults who are not students) is a good future challenge. A second limitation might come from the measuring instrument that is based on self-report and could have biases related to the social desirability.

It is also indispensable to check if the scale is useful to study the relationship between general self-efficacy and learning.

\section{References:}

1. Abalo, J., Lévy, J., Rial, A., \& Varela, J. (2006). Invarianza factorial con muestras múltiples. In J. Lévy (Ed.), Modelización con Estructuras de Covarianzas en Ciencias Sociales (pp. 259-278). Madrid: Netbiblo.

2. Arbuckle, J. R. (2012). AMOS users guide version 21.0. Chicago, IL: Marketing Department, SPSS Incorporated.

3. Asbún, C., \& Ferreira, Y. (2004). Autoeficacia profesional y género en adolescentes de cuarto de secundaria de la zona sur de la ciudad de la paz. Revista Ajayu, 2(1). Retrieved from http://www.ucb.edu.bo/Publicaciones/Ajayu/v2n1/v2n1a3.html

4. Bandura, A. (1982). Self-efficacy mechanism inhuman agency. American Psychologist, 37(2), 122-147.

5. Bandura, A. (1986). Pensamiento y acción. Fundamentos sociales. Madrid: Alianza.

6. Bandura, A. (1997). Self-efficacy: The exercise of Control. New York: Freeman.

7. Blanco, Á. (2010). Creencias de autoeficacia de estudiantes universitarios: un estudio empírico sobre la especificidad del constructo. RELIEVE, 16(1), 1-28.

8. Blanco, H., Ornelas, M., Tristán, J. L., Cocca, A., Mayorga-Vega, D., López-Walle, J., \& Viciana, J. (2013). Editor for creating and applying computerise surveys. Procedia Social and Behavioral Sciences, 106 , 935-940. doi:http://dx.doi.org/10.1016/j.sbspro.2013.12.105 
9. Brzoska, P., \& Razum, O. (2010). Validity Issues in Quantitative Migrant Health Research: The Example of Illness Perceptions. New York, NY: Peter Lang International Academic Publishers.

10. Byrne, B. M. (2010). Structural Equation Modeling With AMOS: Basic Concepts, Applications, and Programming. New York, NY: Routledge.

11. Carbonero, M. Á., \& Merino, E. (2008). Autoeficacia y madurez vocacional. Psicothema, 16(2), 229-234.

12. Elosua, P., \& Zumbo, B. D. (2008). Coeficientes de fiabilidad para escalas de respuesta categórica ordenadas. Psicothema, 20(4), 896901.

13. Gelabert, E., García-Esteve, L., Martín-Santos, R., Gutiérrez, F., Torres, A., \& Subirà, S. (2011). Psychometric properties of the Spanish version of the Frost Multidimensional Perfectionism Scale in women. Psicothema, 23(1), 133-139.

14. Gutiérrez, M., Ampara, E., \& Carminal, P. (2011). Relaciones entre empatía, conducta prosocial, agresividad, autoeficacia y responsabilidad personal y social de los escolares. Psicothema, 23(1), 13-19.

15. Montero, I., \& León, O. (2005). Sistema de clasificación del método en los informes de investigación en Psicología. International Journal of Clinical and Health Psychology, 5, 115-127.

16. Nunnally, J. C., \& Bernstein, I. H. (1995). Teoría Psicométrica. México: McGraw-Hill.

17. Olivari, C., \& Urra, E. (2007). Autoeficacia y conductas de salud. Ciencia y Enfermería, 13(1), 9-15.

18. Ornelas, M., Blanco, H., Gastélum, G., \& Chávez, A. (2012). Autoeficacia Percibida en la conducta Académica de Estudiantes Universitarias. Formación Universitaria, 5(2), 17-26. doi:10.4067/S0718-50062012000200003

19. Ornelas, M., Blanco, H., Rodríguez, J. M., \& Flores, F. J. (2011). Análisis psicométrico de la escala autoeficacia en conductas de cuidado de la salud física en universitarios de primer ingreso. Formación Universitaria, 4(6), 21-34. doi:10.4067/S071850062011000600004

20. Peguero, A. A., \& Shaffer, K. A. (2015). Academic Self-Efficacy, Dropping Out, and the Significance of Inequality. Sociological Spectrum, 35(1), 46-46. doi:10.1080/02732173.2014.978428

21. Pérez, E., Lescano, C., Heredia, D., Zalazar, P., Furlám, L., \& Martínez, M. (2011). Desarrollo y análisis psicométricos de un inventario de autoeficacia para inteligencias múltiples en niños argentinos Psicoperspectivas, 10(1), 169-189. 
22. Revelle, W., \& Zinbarg, R. E. (2009). Coefficients alpha, beta, omega and the glb: comments on Sijtsma. Psychometrika, 74(1), 145154. doi:10.1007/s11336-008-9102-z

23. Sanjuán, P., Pérez, A. M., \& Bermúdez, J. (2000). Escala de autoeficacia general: datos psicométricos de la adaptación para población española. Psicothema, 12(2), 509-513.

24. Schmidt, V., Messoulam, N., \& Molina, F. (2008). Autoconcepto académico en adolescentes de escuelas medias: presentación de un instrumento para su evaluación. Revista Iberoamericana de Diagnóstico y Evaluación Psicológica, 1(25), 81-106.

25. Shkullaku, R. (2013). The relationship between self - efficacy and academic performance in the context of gender among Albanian students. European Academic Research, 1(4), 467-478.

26. Sijtsma, K. (2009). On the use, the misuse, and the very limited usefulness of Cronbach's alpha. Psychometrika, 74(1), 107-120. doi:10.1007/s11336-008-9101-0

27. Thompson, B. (2004). Exploratory and Confirmatory Factor Analysis. Understanding concepts and applications. . Washington, D $\mathrm{C}$ : American Psychological Association.

28. Viciana, J., Cervelló, E. M., \& Ramírez, J. (2007). Effects of manipulating positive and negative feedback on goal orientation, perceived motivational climate, satisfaction, task choice, perception of ability, and attitude to physical education lessons. Perceptual and motor skills, 105(1), 67-82.

29. Zimmerman, B., \& Kitsantas, A. (2005). Homework practice and academic achievement. The mediating role of self-efficacy and perceived responsibility beliefs. Contemporary Educational Psychology, 30(4), 397-417.

Table 1. Descriptive Analysis and discrimination indexes of the scale items "General Self-efficacy". Total sample.

\begin{tabular}{lccccc}
\hline \multicolumn{1}{c}{ Item } & $\mathrm{M}$ & $\mathrm{SD}$ & $\mathrm{AS}$ & $\mathrm{KU}$ & $\mathrm{r}_{\text {i-total }}$ \\
\hline Item 1 & 7.33 & 1.96 & -0.77 & 0.29 & .60 \\
Item 2 & 7.56 & 1.78 & -0.88 & 0.59 & .73 \\
Item 3 & 7.90 & 1.80 & -1.06 & 1.49 & .61 \\
Item 4 & 7.41 & 1.87 & -0.81 & 0.78 & .75 \\
Item 5 & 7.41 & 1.93 & -0.74 & -0.15 & .76 \\
Item 6 & 7.24 & 2.02 & -0.70 & 0.00 & .69 \\
Item 7 & 7.63 & 2.08 & -0.99 & 0.65 & .72 \\
Item 8 & 7.35 & 2.21 & -1.23 & 1.34 & .84 \\
Item 9 & 7.22 & 2.26 & -1.01 & 0.51 & .75 \\
Item 10 & 7.29 & 2.15 & -1.15 & 1.38 & .57 \\
\hline
\end{tabular}

Note: $\mathrm{M}=$ mean; $\mathrm{SD}=$ standard deviation; $\mathrm{AS}=$ asymmetry; $\mathrm{KU}=$ kurtosis; $\mathrm{r}_{\mathrm{i} \text {-total }}=$ corrected item-total correlation. 
Table 2. Absolute, incremental and Parsimony fit indexes for the generated models.

\begin{tabular}{|c|c|c|c|c|c|c|c|c|}
\hline \multirow[b]{2}{*}{ Model } & \multicolumn{3}{|c|}{ Absolute indices } & \multicolumn{3}{|c|}{ Incremental indices } & \multicolumn{2}{|c|}{ Parsimony indices } \\
\hline & $\chi^{2}$ & GFI & RMSEA & AGFI & TLI & CFI & CMIN/DF & AIC \\
\hline $\begin{array}{c}\text { AG-1- } \\
10\end{array}$ & $210.167^{*}$ & .867 & .133 & .792 & .870 & .899 & 6.005 & 250.167 \\
\hline $\begin{array}{c}\text { AG-1- } \\
7\end{array}$ & $40.344^{*}$ & .960 & .082 & .920 & .967 & .978 & 2.882 & 68.344 \\
\hline
\end{tabular}

Note: $* \mathrm{p}<.05 ; \mathrm{GFI}=$ goodness of fit index; RMSEA $=$ root mean square error of approximation; SRMR = Standardized Root Mean Square Residual; AGFI = adjusted goodness of fit index; TLI = Tucker-Lewis index; CFI = comparative fit index; CMIN/DF = chi-squared fit index divided by degrees of freedom; AIC = Akaike information criterion

Table 3 Standardized solutions confirmatory factor analysis for the AG-1-10 Model.

\begin{tabular}{lc}
\hline \multicolumn{1}{c}{ Item } & $\begin{array}{c}\text { Standardized } \\
\text { Regression } \\
\text { Weights }\end{array}$ \\
\hline 1. Find the way to obtain what I want even if someone opposes me & .64 \\
2. Solve difficult problems if I try hard enough & .75 \\
3. Persist in what I have set until I achieve my goals & .64 \\
4. Effectively handle unexpected events & .77 \\
5. Overcome unforeseen situations & .79 \\
6. Remain calm when I am in difficulties & .72 \\
7. turn out triumphant whatever comes & .77 \\
8. Solve most of the problems I face & .88 \\
9. Plan what should I do if I find myself in a difficult situation & .78 \\
10. Generate several alternative solutions when having to deal with a problem & .60 \\
\hline
\end{tabular}

Table 4 Standardized solutions confirmatory factor analysis for the AG-17.Model.

\begin{tabular}{lc}
\hline \multicolumn{1}{c}{ Item } & $\begin{array}{c}\text { Standardized } \\
\text { Regression } \\
\text { Weights }\end{array}$ \\
\hline 2. Solve difficult problems if I try hard enough & .73 \\
4. Effectively handle unexpected events & .76 \\
5. Overcome unforeseen situations & .81 \\
6. Remain calm when I am in difficulties & .73 \\
7. turn out triumphant whatever comes & .78 \\
8. Solve most of the problems I face & .88 \\
9. Plan what should I do if I find myself in a difficult situation & .77 \\
\hline
\end{tabular}

